\title{
Advantage of Dairy for Improving Aging Muscle
}

\author{
Yang Du, Chorong Oh, Jaekyung No* \\ Department of Food and Nutrition, Kyungsung University, Busan, Korea
}

The risk of sarcopenia increases with aging. Malnutrition in the elderly population is an important risk factor for sarcopenia. Calcium (Ca), phosphate (P), vitamin D and protein are key nutrients for the human body and affect muscle mass and quality. Dairy products are rich in these nutrients, which implicates that dairy products might be ideal for elderly population. This systematic review highlights the effects of dairy products on muscle mass, muscle strength and body performance in the elderly population in the perspective of $\mathrm{Ca}$, $\mathrm{P}$, vitamin $\mathrm{D}$ and protein.

Key words: Dairy products, Calcium, Phosphate, Vitamin D, Proteins, Muscle

\author{
Received June 24, 2019 \\ Reviewed July 12, 2019 \\ Accepted August 13, 2019 \\ ${ }^{*}$ Corresponding author \\ Jaekyung No \\ https://orcid.org/0000-0003-2433-346X \\ Department of Food and Nutrition, \\ Kyungsung University, 309 Suyeong-ro, \\ Nam-gu, Busan 48434, Korea \\ Tel: +82-51-663-4651 \\ Fax: +82-51-663-4651 \\ E-mail:jkno3@ks.ac.kr
}

\section{INTRODUCTION}

With the aging process, weakening of muscle strength and quality (sarcopenia) is predicted to be the cause of increased early mortality for the elderly. ${ }^{1}$ With the aging of the long baby-boomer generation, the prevalence of sarcopenia will increase. ${ }^{2}$ Now, there are 50 million patients with sarcopenia in the world and it is forecasted to be 500 million sarcopenia patients in 2050. 3,4 Therefore, aging and sarcopenia have had a serious impact on public health in countries around the world. Moreover, in the elderly population, sarcopenia will undoubtedly become a growing financial burden for the health care system of developed countries. ${ }^{5}$

The muscle is under great pressure. The causes of muscle loss are unclear, but it is apparent that during the development and maintenance of muscle, muscle mass and strength of the aged are under the influence of environmental factors, exercise factors, nutritional factors etc. Among these, nutritional factors play pivotal roles. Appropriate nutritional supplements for the elderly are particularly important for preventing age-related muscle mass and muscle loss (sarcopenia). ${ }^{6}$ A lot of literature have proved that there is a lower basal rate of protein synthesis and/or an increased rate of protein breakdown, and lower sensitivity to insulin-induced stimulation of protein synthesis in the aged muscle, ${ }^{7,8}$ and that vitamin $\mathrm{D}$ can precisely improve insulin resistance and insulin secretion. ${ }^{9,10}$ Moreover, the main active form of vitamin $\mathrm{D}$ after its conversion in vivo is 1,25-dihydroxyvitamin $\mathrm{D}\left(1,25(\mathrm{OH})_{2} \mathrm{D}\right)$, which is an important factor regulating the balance among calcium $(\mathrm{Ca})$, phosphate $(\mathrm{P})$ and muscle metabolism. Therefore, these factors can prevent from the age-related loss of muscle. ${ }^{11,12}$

Dairy products are one of the important supplying sources of $\mathrm{Ca}, \mathrm{P}$, vitamin $\mathrm{D}$ and protein in diet. Dairy products contain almost all the essential nutrients that promote growth and maintain the health of the elderly and have been confirmed in most studies. ${ }^{13,14}$ Therefore, the health effects of dairy consumption in elderly patients with sarcopenia should be given more attention. This paper explores literature and clinical evidence, and provides information 
for health professionals to help older people with sarcopenia make informed decisions about consumption of dairy products as a part of balanced diet.

\section{SKELETAL MUSCLE HEALTH}

\section{The changes in muscle with aging}

Muscle plays an essential role in the health of the elderly. Muscle mass corresponds to approximately $40 \%$ of body mass. ${ }^{15}$ The quality and strength of skeletal muscle usually peaks at the ages of 20 to 35 years. ${ }^{16}$ After that, there will be $3 \%$ to $8 \%$ muscle mass loss every 10 years and the loss usually accelerates after age of 60 years. ${ }^{8,17-20}$ With aging, the quality and strength of skeletal muscles decline. It is reported that the incidence rate of sarcopenia among the elderly aged 60 years and above reaches $30 \%$, and the elderly aged 80 years and above can reach more than 50\%. ${ }^{19}$ Muscle strength decreases with aging. In the meantime, it has recently been reported to predict the onset of sarcopenia. ${ }^{21}$ It is caused by an imbalance between protein synthesis and degradation. There are several mechanisms causing the declination of age-related muscle mass and strength, including altered hormonal status, inflammatory processes, reduced physical activity, and undernutrition, most often resulting from undernutrition. $^{22}$

\section{Undernutrition in elderly and sarcopenia}

As early as the 1990s, Castaneda et al. ${ }^{23}$ found that older women had a decrease in lean body mass and decreased muscle function on a low-protein diet. Campbell et al. ${ }^{24}$ also found that skeletal muscle growth was significantly higher in people with high protein intake than in low protein intake. In the review by Wilson and Morley ${ }^{25}$ loss of appetite and malnutrition caused a decrease in muscle mass and an increase in fat mass. This is mainly because as the nu- tritional intake of the elderly is unbalanced, the protein consumption in the body increases. In addition, the relative synthesis is insufficient, resulting in a decrease in muscle mass. Most elderly people have decreased appetite and inadequate nutrient intake. In addition, the clinical development of many wasting diseases and most malignant tumors will consume different levels of protein in the body, which will lead to imbalance of protein synthesis, catabolism and muscle reduction.

\section{The nutrient profile of dairy products}

Eating habits are influenced by diverse factors, even in some developed countries, like Republic of Korea. The eating habits are also affected by age, income, educational level and other factors. These factors lead to various personal nutrition consumption, even in innutrition. Eating habits and various factors which consists of age, income level, educational level, personal nutrient consumption, etc. affect many countries of the world, like Republic of Korea. $^{26,27}$

Hence, dietary guidance needs to identify foods that are nutrient rich, affordable, and appealing. ${ }^{28}$ The analysis of the nutritional composition of the Korean diet in 2007 and Food and Agriculture Organization of the United Nations in 2013 showed that the micronutrients in dairy products were rich in content and high in content (Table 1), and the price was relatively low. ${ }^{27}$ In addition, according to other studies, the energy of dairy products is relatively low, and low-fat dairy products, high-Ca dairy products are essential for elderly people with sarcopenia. ${ }^{29}$ Therefore, it is instrumental and necessary to, first, determine which kind of nutrients play the significant role in muscle development and maintenance; second, identify how these essential nutrients interact in muscle development and maintenance; finally, develop appropriate and reasonable dietary methods to prevent the occurrence of diseases, for ex-

Table 1. Nutrient content of the selected dairy foods (per $100 \mathrm{~g}$ )

\begin{tabular}{|c|c|c|c|c|c|c|}
\hline Food name & Energy (kcal) & Total fat (g) & Carbohydrate $(\mathrm{g})$ & Protein $(g)$ & Calcium (mg) & Phosphorus (mg) \\
\hline Milk (3.7\% milkfat) & 64 & 3.7 & 4.7 & 3.3 & 119 & 93 \\
\hline Milk (skimmed without added vitamin A and vitamin D) & 34 & 0.1 & 5.0 & 3.4 & 122 & 101 \\
\hline Yoghurt (low fat) & 63 & 1.6 & 7 & 5.3 & 183 & 144 \\
\hline Yoghurt (fruit, low fat) & 105 & 1.4 & 18.6 & 4.9 & 169 & 133 \\
\hline Cheese (cheddar ) & 403 & 33.1 & 1.3 & 24.9 & 721 & 512 \\
\hline Cheese (non-fat) & 72 & 0.3 & 6.7 & 10.3 & 86 & 190 \\
\hline Ice cream & 207 & 11.0 & 23.6 & 3.5 & 128 & 105 \\
\hline
\end{tabular}


ample, sarcopenia is through food surveys which can provide relative dietary patterns. ${ }^{29,30}$

\section{Influence of dairy products on muscle health}

The potential impact of dairy products on muscle building should be taken seriously. In the daily diet, the supplement of $\mathrm{Ca}, \mathrm{P}$, vitamin $\mathrm{D}$, and protein can be achieved by drinking milk. The beneficial effect of $\mathrm{Ca}, \mathrm{P}$ and protein can enhance muscle mass and function. ${ }^{31,32}$ Vitamin D levels in dairy products are variable and insufficient to meet body needs. After investigation, at least of $20 \mu \mathrm{g}$ (800 IU) per day is needed in healthy adults, the demand was expected to be higher for the elderly. ${ }^{33-35}$ The 2002 review article from the Institute of Clinical Osteology, Germany illustrated that vitamin $\mathrm{D}$ plays a pivotal adjective role in $\mathrm{Ca}^{2+}$ transport and protein synthesis in muscle cells. ${ }^{36}$

In developed countries, such as the United States and Canada, dairy products have become an important part of diet and dairy products in the market often strengthen $\mathrm{Ca}$ and vitamin $\mathrm{D} .{ }^{37,38} \mathrm{In}$ addition, skeletal muscle mass is determined by net balance between synthesis of new proteins and degradation of existing proteins. Daily turnover of skeletal muscle protein in healthy humans is around 1\%-2\% per day. ${ }^{39}$ Protein synthesis increases with increased diet while decreases during fasting. In the elderly population, the postprandial response of protein synthesis is decreased. However, this lower rate of muscle protein synthesis may be a key factor in aging sarcopenia. ${ }^{40}$ Studies have indicated that vitamin $\mathrm{D}$ deficiency can reduce the ability of the intestinal mucosa to fully absorb $\mathrm{Ca}$ and $\mathrm{P}$, which is the strong evidence of significance of vitamin D. However, clinical data also explains how and when nutrients rich in dairy products improve muscle maintenance in adults. ${ }^{41}$ As a result of aging, the muscle mass can reduce and lead to the imbalance of muscle reinforcement and decomposition. Thereaf-

Table 2. Overview of the studies included in the systematic review

\begin{tabular}{|c|c|c|c|c|c|}
\hline Author (year) & $\begin{array}{l}\text { Study population/age/ } \\
\text { place of study }\end{array}$ & Intervention & $\begin{array}{l}\text { Treatment } \\
\text { duration }\end{array}$ & Outcome measurement & Effect on outcome \\
\hline $\begin{array}{l}\text { Bonjour et al. } \\
(2013)^{12}\end{array}$ & $\begin{array}{l}\text { 2,066 Men and } \\
\text { women/range, } \\
\text { 70-79 yr/USA }\end{array}$ & Daily protein intake (0.7 and $1.1 \mathrm{~g} / \mathrm{kg}$ b.w.) & $3 \mathrm{yr}$ & $\begin{array}{l}\text { Appendicular lean } \\
\text { mass }\end{array}$ & $\begin{array}{l}\text { The group of daily protein intake }(0.7 \mathrm{~g} / \mathrm{kg} \text { b.w.) is } \\
40 \% \text { less of appendicular lean mass than the } \\
\text { group of daily protein intake ( } 1.1 \mathrm{~g} / \mathrm{kg} \text { b.w.). }\end{array}$ \\
\hline $\begin{array}{l}\text { Björkman et al. } \\
(2011)^{42}\end{array}$ & $\begin{array}{l}47 \text { Older people/over } \\
69.5 \mathrm{yr} / \text { Helsinki, } \\
\text { Finland }\end{array}$ & $\begin{array}{l}\text { A whey protein enriched dairy product with } \\
\text { high leucine content }\end{array}$ & 8 wk & $\begin{array}{l}\text { Lower limb muscle } \\
\text { mass }\end{array}$ & A $1.8 \%$ increase in lower limb muscle mass \\
\hline $\begin{array}{l}\text { Mojtahedi et al. } \\
(2011)^{44}\end{array}$ & $\begin{array}{l}31 \text { Overweight or obese, } \\
\text { postmenopausal } \\
\text { women/mean } \pm S D \text {, } \\
65.2 \pm 4.6 \mathrm{yr} / \mathrm{USA}\end{array}$ & $\begin{array}{l}\text { Prescribed a reduced calorie diet } \\
(1,400 \mathrm{kcal} / \text { day) and randomly assigned to } \\
50 \mathrm{~g} / \text { day whey protein ( } 15 \text { participants } \\
\text { with protein and } 16 \text { participants without). }\end{array}$ & 6 mon & Muscle and weight & $\begin{array}{l}15 \text { Participants with protein maintain muscle } \\
\text { relative weight loss. }\end{array}$ \\
\hline $\begin{array}{l}\text { Melanson et al. } \\
(2005)^{47}\end{array}$ & $\begin{array}{l}10 \text { Men and } 9 \\
\text { women/range, } \\
20-50 \text { yr/USA }\end{array}$ & $\begin{array}{l}\text { High-dairy ( } 3 \text { to } 4 \text { servings per day, 1,400 mg } \\
\mathrm{Ca}^{2+} / \text { day) energy balance diet }\end{array}$ & $1 \mathrm{wk}$ & BMl and body mass & $\begin{array}{l}\text { Increased consumption of dairy products in the } \\
\text { short term may affect the reduction of BMl and } \\
\text { the increase of body mass }\end{array}$ \\
\hline $\begin{array}{l}\text { Rozenberg et al. } \\
(2016)^{13}\end{array}$ & $\begin{array}{l}116 \text { Healthy prepubertal } \\
\text { boys } / \text { mean } \pm S D \text {, } \\
7.4 \pm 0.4 \mathrm{yr} / \text { Switzerland }\end{array}$ & Providing $850 \mathrm{mg} /$ day calcium & $1 \mathrm{yr}$ & $\begin{array}{l}\text { Weight, fat mass, } \\
\text { waist circumference } \\
\text { and lean body mass }\end{array}$ & $\begin{array}{l}\text { A possible small weight reduction, with decreases } \\
\text { in fat mass and waist circumference and } \\
\text { increases in lean body mass }\end{array}$ \\
\hline $\begin{array}{l}\text { Schürch et al. } \\
(1998)^{32}\end{array}$ & $\begin{array}{l}82 \text { Orthopedic ward } \\
\text { patients/mean } \pm S D \\
80.7 \pm 7.4 \mathrm{yr} / \mathrm{USA}\end{array}$ & $\begin{array}{l}\text { Received calcium supplementation, } \\
550 \mathrm{mg} / \text { day, and } 1 \text { dose of vitamin } \mathrm{D} \text {, } \\
200,000 \mathrm{IU}\end{array}$ & 6 mon & Biceps muscle strength & Found the incremental of biceps muscle strength. \\
\hline
\end{tabular}

b.w., body weight; ASMM, appendicular skeletal muscle mass; SD, standard deviation; BMI, body mass index. 
ter, the supplement of dairy products has been postulated to prevent further loss of lean mass and promote muscle accretion and enhanced function (Table 2).

\section{The beneficial effects of nutrients on sarcopenia}

The cause of sarcopenia is unclear for now, but it is obvious that many causes are associated with undernutrition in the elderly. Undernutrition results in decreased muscle synthesis and increased rate of decomposition. The nutrients that cause nutrients for muscle synthesis and decomposition includes $\mathrm{Ca}, \mathrm{P}$, vitamin $\mathrm{D}$, and protein. Also, in the previous studies, ${ }^{7,48}$ they have proved that it is the key to cause muscle reduction. However, as other, no dietary factors are involved. Sarcopenia is considered to be a multifactorial disease. Regardless of its causes, nutritional supplements appear to play a significant role in preventing and reversing health and loss of muscle and function in the elderly. ${ }^{49,50}$ The ability to reverse this situation is to apply nutrient-rich dairy products as a dietary strategy to prevent sarcopenia, which is based on the multi-nutrient supplements in dairy products that can supplement muscle production and increase body lean body mass.

The protein in dairy products, especially casein and whey, is the highest quality protein. In 2007, Wilkinson et al. ${ }^{45}$ found that milk can promote better muscle protein increase compared to plant protein after exercise. In addition, Du et al. ${ }^{51}$ also proved that animal protein can effectively increase muscle mass in healthy young males. Another study shows that nutrient-rich dairy protein, which is abundant with protein, can increase protein synthesis in muscle. ${ }^{52}$ Moreover, in the elderly population, conducted studies with dairy products (such as ricotta and milk) used for clinical intervention studies of muscle mass and strength turned out to be unsuccessful. ${ }^{42,53,54}$ Nevertheless, it is worth noting that the study mentions that the use of milk protein concentrating on supplement proteins for the elderly has a potential for the future development. ${ }^{55}$ Protein can promote muscle formation. Increasing dietary protein intake is the basis for inhibiting muscle loss. Leucine intake promotes muscle protein synthesis and inhibits protein degradation. ${ }^{56}$ Moreover, amino acids are essential for the synthesis of intracellular and extracellular proteins. Furthermore, proteins can also indirectly affect $\mathrm{Ca}$ balance and muscle metabolism. The results of current research indicate that adequate intake of protein-source foods during the mid- dle-adult years may play a salient role in the maintenance of skeletal muscle mass into the older-adult years. ${ }^{56}$ In other studies, protein, particularly from animal sources, has been linked with limb muscle mass and total body muscle in older adults. ${ }^{57-60}$

Also, a protein-mediated not only increases the incremental of insulin-like growth factors- 1 , but also produces $1,25(\mathrm{OH})_{2} \mathrm{D}$, which also affects the absorption of $\mathrm{Ca}$ and $\mathrm{P}$ in the intestine. ${ }^{61} \mathrm{In}$ crease of $\mathrm{Ca}$ and $\mathrm{P}$ in the body cells has a positive effect on the muscles. ${ }^{47}$ In addition, studies by Zemel and the colleagues ${ }^{46,62,63}$ indicated that increasing dietary $\mathrm{Ca}$ and protein intake causes a decrease in circulating $1,25(\mathrm{OH})_{2} \mathrm{D}_{3}$ concentration resulting in creation of environment that promotes lipolysis and inhibits lipogenesis, and promotes muscle synthesis.

There is plenty of $\mathrm{Ca}$ in the dairy products. In the study of Waters et al..$^{64}$ the high intake of $\mathrm{Ca}$, and in the study of Seo et al. ${ }^{65}$ the low intake of $\mathrm{Ca}(<415 \mathrm{mg} /$ day), all revealed the linkage between $\mathrm{Ca}$ and muscle mass while the results of these two studies also illustrated that lower $\mathrm{Ca}$ intake can play a better role in the prevention and treatment of sarcopenia in the elderly. The results of other studies also further confirmed that the reduced $\mathrm{Ca}$ absorption and changes in Ca homeostasis are associated with sarcopenia in the elderly. ${ }^{6,67}$ In vivo absorption of Ca may require the assistance of vita$\min \mathrm{D}$, but other animal studies have shown that $\mathrm{Ca}$ uptake is also possible through passive absorption. ${ }^{68} \mathrm{~A}$ study by Waters et al., ${ }^{64}$ found that vitamin $\mathrm{D}$ intake was significantly lower in elderly people with sarcopenia, but it did not provide serum $25(\mathrm{OH})_{2} \mathrm{D}$ levels. However, most dairy products on the market have already strengthened $\mathrm{Ca}$ and vitamin $\mathrm{D}$, which can be conducted to meet the needs of the elderly. Ca and vitamin D play key roles in regulating body muscles. Among the elderly population, the high incidence of sarcopenia usually coexists with insufficient intake of $\mathrm{Ca}$ and vitamin D. There are some empirical studies showing that for the elderly in France (average 84 years), with the supplement of vitamin D and $\mathrm{Ca}$ for 18 months, the muscle quality improved significantly. ${ }^{69} \mathrm{An}$ other study has replicated these results in the United States. ${ }^{70} \mathrm{Al}-$ though these two researches have both mentioned that the function to improve muscle, the elaboration for the starting stage to get better was not revealed. However, it has verified that oral vitamin D appears to reduce the risk of muscle mass loss only when Ca supplementation is added. 
Ultimately, P stimulates the nerves and muscles, causing the heart and muscles to contract regularly. $\mathrm{P}$ helps cell division, proliferation, and protein synthesis, passing genetic characteristics from the previous generation to the next generation. $\mathrm{P}$ ions are essential for the metabolism of carbohydrates, lipids and proteins. They act as cofactors on a wide range of enzyme systems and also in high energy $\mathrm{P}$ compounds. Organic $\mathrm{P}$, adenosine triphosphate, creating $\mathrm{P}$, etc. have the effect of storing and transferring energy. The balance of $\mathrm{Ca}$ and $\mathrm{P}$ contributes to the utilization of inorganic salts during bone development and maturation. P can regulate the metabolism of vitamin D and maintain the stability of Ca. Moreover, elevated serum $P$ levels were independently associated with increased mortality risk among sarcopenia patients with chronic kidney disease. ${ }^{71,72}$

In conclusion, this study synthesized and determined the importance of adding dairy products to the diet. The role of maintaining a healthy diet for muscle synthesis, muscle strength and even in old age is significant. The findings of this study are capable of providing evidence of the development of potential dietary strategies, such as improving the intake of dairy products in the elderly and improving muscle health in the elderly.

\section{CONCLUSION}

Dairy products provide nutrients for the elderly, maintain muscle health, prevent multiple physiological mechanisms, and interact with skeletal muscle mass and function to help prevent sarcopenia. Therefore, the risk of sarcopenia can be alleviated by appropriate nutrition measures in the elderly. In particular, increase in the intake of nutrient-rich dairy products improves muscles, reduces the loss of muscle strength, does not increase the incidence of metabolic diseases and chronic diseases, and has no side effects of increased fat and kidney function. Therefore, results of this study suggest that adding dairy products to a habitual diet may be a promising dietary improvement strategy. Ultimately, this dietary strategy may prevent muscle reduction in the elderly population.

\section{CONFLICTS OF INTEREST}

The authors declare no conflict of interest.

\section{ACKNOWLEDGMENTS}

This research was supported by Kyungsung University in 2019, Busan, Korea.

\section{AUTHOR CONTRIBUTIONS}

Study concept and design: all authors; acquisition of data: YD; analysis and interpretation of data: YD; drafting of the manuscript: YD; critical revision of the manuscript: all authors; statistical analysis: YD; obtained funding: JN; administrative, technical, or material support: JN; and study supervision: all authors.

\section{REFERENCES}

1. Wandrag L, Brett SJ, Frost G, Hickson M. Impact of supplementation with amino acids or their metabolites on muscle wasting in patients with critical illness or other muscle wasting illness: a systematic review. J Hum Nutr Diet 2015;28:313-30.

2. Roubenoff R. Sarcopenic obesity: the confluence of two epidemics. Obes Res 2004;12:887-8.

3. Shim JE, Paik HY, Lee SY, Moon HK, Kim YO. Comparative analysis and evaluation of dietary intake of Koreans by age groups: (4) the Korean diet quality index. Korean J Nutr 2002; 35:558-70.

4. Song YJ, Joung HJ, Paik HY. Socioeconomic, nutrient, and health risk factors associated with dietary patterns in adult populations from 2001 Korean National Health and Nutrition Survey. Korean J Nutr 2005;38:219-25.

5. Janssen I, Shepard DS, Katzmarzyk PT, Roubenoff R. The healthcare costs of sarcopenia in the United States. J Am Geriatr Soc 2004;52:80-5.

6. Morley JE. Sarcopenia: diagnosis and treatment. J Nutr Health Aging 2008; 12:452-6.

7. Valenzuela RE, Ponce JA, Morales-Figueroa GG, Muro KA, Carreón VR, Alemán-Mateo H. Insufficient amounts and inadequate distribution of dietary protein intake in apparently healthy older adults in a developing country: implications for dietary strategies to prevent sarcopenia. Clin Interv Aging 2013; 8:1143-8. 
8. Paddon-Jones D, Rasmussen BB. Dietary protein recommendations and the prevention of sarcopenia. Curr Opin Clin Nutr Metab Care 2009;12:86-90.

9. Ardabili HR, Gargari BP, Farzadi L. Vitamin D supplementation has no effect on insulin resistance assessment in women with polycystic ovary syndrome and vitamin $\mathrm{D}$ deficiency. Nutr Res 2012;32:195-201.

10. Roth CL, Elfers C, Kratz M, Hoofnagle AN. Vitamin D deficiency in obese children and its relationship to insulin resistance and adipokines. J Obes 2011;2011:495101.

11.Zhu K, Kerr DA, Meng X, Devine A, Solah V, Binns CW, et al. Two-year whey protein supplementation did not enhance muscle mass and physical function in well-nourished healthy older postmenopausal women. J Nutr 2015;145:2520-6.

12. Bonjour JP, Kraenzlin M, Levasseur R, Warren M, Whiting S. Dairy in adulthood: from foods to nutrient interactions on bone and skeletal muscle health. J Am Coll Nutr 2013;32:251-63.

13. Rozenberg S, Body JJ, Bruyère $\mathrm{O}$, Bergmann P, Brandi ML, Cooper $\mathrm{C}$, et al. Effects of dairy products consumption on health: benefits and beliefs: a commentary from the Belgian Bone Club and the European Society for Clinical and Economic Aspects of Osteoporosis, Osteoarthritis and Musculoskeletal Diseases. Calcif Tissue Int 2016;98:1-17.

14. Borack MS, Reidy PT, Husaini SH, Markofski MM, Deer RR, Richison $\mathrm{AB}$, et al. Soy-dairy protein blend or whey protein isolate ingestion induces similar postexercise muscle mechanistic target of rapamycin complex 1 signaling and protein synthesis responses in older men. J Nutr 2016;146:2468-75.

15. Diem K, Lentner C. Tables scientifiques. Basel: Ciba-Geigy; 1972.

16. Holloszy JO. The biology of aging. Mayo Clin Proc 2000;75 Suppl:S3-8.

17. Lindle RS, Metter EJ, Lynch NA, Fleg JL, Fozard JL, Tobin J, et al. Age and gender comparisons of muscle strength in 654 women and men aged 20-93 yr. J Appl Physiol (1985) 1997; 83:1581-7.

18. Lynch NA, Metter EJ, Lindle RS, Fozard JL, Tobin JD, Roy TA, et al. Muscle quality: I. age-associated differences between arm and leg muscle groups. J Appl Physiol (1985) 1999;86: 188-94.
19. Baumgartner RN, Koehler KM, Gallagher D, Romero L, Heymsfield SB, Ross RR, et al. Epidemiology of sarcopenia among the elderly in New Mexico. Am J Epidemiol 1998;147:755-63.

20. Janssen I, Heymsfield SB, Ross R. Low relative skeletal muscle mass (sarcopenia) in older persons is associated with functional impairment and physical disability. J Am Geriatr Soc 2002;50:889-96.

21.Lang T, Cauley JA, Tylavsky F, Bauer D, Cummings S, Harris TB, et al. Computed tomographic measurements of thigh muscle cross-sectional area and attenuation coefficient predict hip fracture: the health, aging, and body composition study. J Bone Miner Res 2010;25:513-9.

22. Doherty TJ. Invited review: aging and sarcopenia. J Appl Physiol (1985) 2003;95:1717-27.

23. Castaneda C, Charnley JM, Evans WJ, Crim MC. Elderly women accommodate to a low-protein diet with losses of body cell mass, muscle function, and immune response. Am J Clin Nutr $1995 ; 62: 30-9$.

24. Campbell WW, Barton ML Jr, Cyr-Campbell D, Davey SL, Beard JL, Parise G, et al. Effects of an omnivorous diet compared with a lactoovovegetarian diet on resistance-training-induced changes in body composition and skeletal muscle in older men. Am J Clin Nutr 1999;70:1032-9.

25. Wilson MM, Morley JE. Invited review: aging and energy balance. J Appl Physiol (1985) 2003;95:1728-36.

26. Drewnowski A. The cost of US foods as related to their nutritive value. Am J Clin Nutr 2010;92:1181-8.

27. Wang Y, Beydoun MA. The obesity epidemic in the United States: gender, age, socioeconomic, racial/ethnic, and geographic characteristics. A systematic review and meta-regression analysis. Epidemiol Rev 2007;29:6-28.

28. Drewnowski A. The contribution of milk and milk products to micronutrient density and affordability of the U.S. diet. J Am Coll Nutr 2011;30(5 Suppl 1):422S-428S.

29. Hannan MT, Tucker KL. The influence of food groups upon bone health. Cambridge: The Royal Society of Chemistry; 2003.

30. Holick MF, Dawson-Hughes B. Nutrition and bone health. Totowa (NJ): Humana Press; 2004.

31. McGregor RA, Poppitt SD. Milk protein for improved meta- 
bolic health: a review of the evidence. Nutr Metab (Lond) 2013;10:46.

32. Schürch MA, Rizzoli R, Slosman D, Vadas L, Vergnaud P, Bonjour JP. Protein supplements increase serum insulin-like growth factor-I levels and attenuate proximal femur bone loss in patients with recent hip fracture: a randomized, double-blind, placebo-controlled trial. Ann Intern Med 1998;128:801-9.

33. Dawson-Hughes B, Mithal A, Bonjour JP, Boonen S, Burckhardt P, Fuleihan GE, et al. IOF position statement: vitamin D recommendations for older adults. Osteoporos Int 2010;21: 1151-4.

34. Hanley DA, Cranney A, Jones G, Whiting SJ, Leslie WD, Cole $\mathrm{DE}$, et al. Vitamin D in adult health and disease: a review and guideline statement from Osteoporosis Canada. CMAJ 2010; 182:E610-8.

35. Bischoff-Ferrari HA, Willett WC, Orav EJ, Lips P, Meunier PJ, Lyons RA, et al. A pooled analysis of vitamin $\mathrm{D}$ dose requirements for fracture prevention. N Engl J Med 2012;367:40-9.

36. Pfeifer M, Begerow B, Minne HW. Vitamin D and muscle function. Osteoporos Int 2002;13:187-94.

37. Calvo MS, Whiting SJ, Barton CN. Vitamin D fortification in the United States and Canada: current status and data needs. Am J Clin Nutr 2004;80(6 Suppl):1710S-1716S.

38. O’Donnell S, Cranney A, Horsley T, Weiler HA, Atkinson SA, Hanley DA, et al. Efficacy of food fortification on serum 25hydroxyvitamin D concentrations: systematic review. Am J Clin Nutr 2008;88:1528-34.

39. Atherton PJ, Smith K. Muscle protein synthesis in response to nutrition and exercise. J Physiol 2012;590:1049-57.

40. Volpi E, Mittendorfer B, Rasmussen BB, Wolfe RR. The response of muscle protein anabolism to combined hyperaminoacidemia and glucose-induced hyperinsulinemia is impaired in the elderly. J Clin Endocrinol Metab 2000;85:4481-90.

41. Bonjour JP. Calcium and phosphate: a duet of ions playing for bone health. J Am Coll Nutr 2011;30(5 Suppl 1):438S-448S.

42. Björkman MP, Pilvi TK, Kekkonen RA, Korpela R, Tilvis RS. Similar effects of leucine rich and regular dairy products on muscle mass and functions of older polymyalgia rheumatica patients: a randomized crossover trial. J Nutr Health Aging 2011;15:462-7.
43. Alemán-Mateo H, Carreón VR, Macías L, Astiazaran-García H, Gallegos-Aguilar AC, Enríquez JR. Nutrient-rich dairy proteins improve appendicular skeletal muscle mass and physical performance, and attenuate the loss of muscle strength in older men and women subjects: a single-blind randomized clinical trial. Clin Interv Aging 2014;9:1517-25.

44. Mojtahedi MC, Thorpe MP, Karampinos DC, Johnson CL, Layman DK, Georgiadis JG, et al. The effects of a higher protein intake during energy restriction on changes in body composition and physical function in older women. J Gerontol A Biol Sci Med Sci 2011;66:1218-25.

45. Wilkinson SB, Tarnopolsky MA, Macdonald MJ, Macdonald JR, Armstrong D, Phillips SM. Consumption of fluid skim milk promotes greater muscle protein accretion after resistance exercise than does consumption of an isonitrogenous and isoenergetic soy-protein beverage. Am J Clin Nutr 2007;85:1031-40. 46.Zemel MB, Richards J, Mathis S, Milstead A, Gebhardt L, Silva E. Dairy augmentation of total and central fat loss in obese subjects. Int J Obes (Lond) 2005;29:391-7.

47. Melanson EL, Donahoo WT, Dong F, Ida T, Zemel MB. Effect of low- and high-calcium dairy-based diets on macronutrient oxidation in humans. Obes Res 2005;13:2102-12.

48. Malafarina V, Uriz-Otano F, Iniesta R, Gil-Guerrero L. Effectiveness of nutritional supplementation on muscle mass in treatment of sarcopenia in old age: a systematic review. J Am Med Dir Assoc 2013;14:10-7.

49. Tieland M, van de Rest O, Dirks ML, van der Zwaluw N, Mensink $\mathrm{M}$, van Loon LJ, et al. Protein supplementation improves physical performance in frail elderly people: a randomized, double-blind, placebo-controlled trial. J Am Med Dir Assoc 2012;13:720-6.

50. Oh C, Jho S, No JK, Kim HS. Body composition changes were related to nutrient intakes in elderly men but elderly women had a higher prevalence of sarcopenic obesity in a population of Korean adults. Nutr Res 2015;35:1-6.

51. Du Y, Oh C, No J. Associations between sarcopenia and metabolic risk factors: a systematic review and meta-analysis. J Obes Metab Syndr 2018;27:175-85.

52. Hartman JW, Tang JE, Wilkinson SB, Tarnopolsky MA, Lawrence RL, Fullerton AV, et al. Consumption of fat-free fluid 
milk after resistance exercise promotes greater lean mass accretion than does consumption of soy or carbohydrate in young, novice, male weightlifters. Am J Clin Nutr 2007;86:373-81.

53. Iglay HB, Apolzan JW, Gerrard DE, Eash JK, Anderson JC, Campbell WW. Moderately increased protein intake predominately from egg sources does not influence whole body, regional, or muscle composition responses to resistance training in older people. J Nutr Health Aging 2009;13:108-14.

54. Alemán-Mateo H, Macías L, Esparza-Romero J, AstiazaranGarcía H, Blancas AL. Physiological effects beyond the significant gain in muscle mass in sarcopenic elderly men: evidence from a randomized clinical trial using a protein-rich food. Clin Interv Aging 2012; 7:225-34.

55. Tieland M, Dirks ML, van der Zwaluw N, Verdijk LB, van de Rest O, de Groot LC, et al. Protein supplementation increases muscle mass gain during prolonged resistance-type exercise training in frail elderly people: a randomized, double-blind, placebo-controlled trial. J Am Med Dir Assoc 2012;13:713-9.

56. Bradlee ML, Mustafa J, Singer MR, Moore LL. High-protein foods and physical activity protect against age-related muscle loss and functional decline. J Gerontol A Biol Sci Med Sci 2017; 73:88-94.

57. Isanejad M, Mursu J, Sirola J, Kröger H, Rikkonen T, Tuppurainen $\mathrm{M}$, et al. Association of protein intake with the change of lean mass among elderly women: the Osteoporosis Risk Factor and Prevention - Fracture Prevention Study (OSTPREFPS). J Nutr Sci 2015;4:e41.

58. Houston DK, Nicklas BJ, Ding J, Harris TB, Tylavsky FA, Newman $A B$, et al. Dietary protein intake is associated with lean mass change in older, community-dwelling adults: the Health, Aging, and Body Composition (Health ABC) Study. Am J Clin Nutr 2008;87:150-5.

59. Meng X, Zhu K, Devine A, Kerr DA, Binns CW, Prince RL. A 5-year cohort study of the effects of high protein intake on lean mass and BMC in elderly postmenopausal women. J Bone Miner Res 2009;24:1827-34.

60. Scott D, Blizzard L, Fell J, Giles G, Jones G. Associations between dietary nutrient intake and muscle mass and strength in community-dwelling older adults: the Tasmanian Older Adult Cohort Study. J Am Geriatr Soc 2010;58:2129-34.
61.Xue B, Moustaid-N, Wilkison WO, Zemel MB. The agouti gene product inhibits lipolysis in human adipocytes via a Ca2+-dependent mechanism. FASEB J 1998;12:1391-6.

62.Zemel MB, Shi H, Greer B, Dirienzo D, Zemel PC. Regulation of adiposity by dietary calcium. FASEB J 2000;14:1132-8.

63. Jones BH, Kim JH, Zemel MB, Woychik RP, Michaud EJ, Wilkison WO, et al. Upregulation of adipocyte metabolism by agouti protein: possible paracrine actions in yellow mouse obesity. Am J Physiol 1996;270(1 Pt 1):E192-6.

64. Waters DL, Wayne SJ, Andrieu S, Cesari M, Villareal DT, Garry $\mathrm{P}$, et al. Sexually dimorphic patterns of nutritional intake and eating behaviors in community-dwelling older adults with normal and slow gait speed. J Nutr Health Aging 2014;18:228-33. 65. Seo MH, Kim MK, Park SE, Rhee EJ, Park CY, Lee WY, et al. The association between daily calcium intake and sarcopenia in older, non-obese Korean adults: the fourth Korea National Health and Nutrition Examination Survey (KNHANES IV) 2009. Endocr J 2013;60:679-86.

66. Brotto M. Aging, sarcopenia and store-operated calcium entry: a common link? Cell Cycle 2011;10:4201-2.

67. Fleet JC, Schoch RD. Molecular mechanisms for regulation of intestinal calcium absorption by vitamin $\mathrm{D}$ and other factors. Crit Rev Clin Lab Sci 2010;47:181-95.

68. Oehlke K, Adamiuk M, Behsnilian D, Gräf V, Mayer-Miebach E, Walz E, et al. Potential bioavailability enhancement of bioactive compounds using food-grade engineered nanomaterials: a review of the existing evidence. Food Funct 2014;5: 1341-59.

69. Chapuy MC, Arlot ME, Duboeuf F, Brun J, Crouzet B, Arnaud S, et al. Vitamin D3 and calcium to prevent hip fractures in elderly women. N Engl J Med 1992;327:1637-42.

70. Tunick MH, Van Hekken DL. Dairy products and health: recent insights. J Agric Food Chem 2015;63:9381-8.

71. Kestenbaum B, Sampson JN, Rudser KD, Patterson DJ, Seliger SL, Young B, et al. Serum phosphate levels and mortality risk among people with chronic kidney disease. J Am Soc Nephrol 2005;16:520-8.

72. Eddington H, Hoefield R, Sinha S, Chrysochou C, Lane B, Foley RN, et al. Serum phosphate and mortality in patients with chronic kidney disease. Clin J Am Soc Nephrol 2010;5: 2251-7. 